\title{
Duodenum and Ampulla of Vater Neuroendocrine Tumor pT1 TNM Finding v8
}

National Cancer Institute

\section{Source}

National Cancer Institute. Duodenum and Ampulla of Vater Neuroendocrine Tumor PT1

TNM Finding v8. NCI Thesaurus. Code C135067.

Duodenum neuroendocrine tumor invading the mucosa or submucosa only and is equal or less than $1 \mathrm{~cm}$; Ampulla of Vater neuroendocrine tumor measuring $1 \mathrm{~cm}$ or less and is confined within the sphincter of Oddi. (from AJCC 8th Ed.) 